\title{
The Characteristics of the Board of Directors and their Impact on the Delay of the External Auditor's Report by Applying to Companies Listed on the Egyptian Stock Exchange
}

Mohamed Abd Elmenam Elshawarby*

Department of Accounting, High Institute of Computer Science and Information Systems, New Cairo Academy, Egypt

\begin{abstract}
This study aimed to identify the effect of the characteristics of the Board of Directors (the size of the Board of Directors, Duality of the Board of Directors, and the balance between executive and non-executive members of the Board of Directors, Board independence, the experience of the Board of Directors) on the delay of the issuance of the audit report. The sample of the study was (16) listed companies on the Egyptian Stock Exchange during the period (2013-2016). The required data were obtained from the published annual reports of the sample companies on the Egyptian Stock Exchange website. Multiple regression analysis was used to test the hypotheses of the study; the study reached the most important results of the impact of the Board size, Board independence and the experience of the Board of Directors to delay the issuance of the independent audit report. One of the most important recommendations of the study is the need for legislation at the local and global level that enhances the characteristics of the board of directors in companies and its impact on delaying the issuance of the independent audit report so that it becomes mandatory for companies which in turn enhances the credibility and reliability of the financial statements, In addition to Conduct more future studies on the same topic of research for its importance.
\end{abstract}

Keywords: The characteristics of the board of directors; Delay of the external auditor's report; Egyptian stock exchange

\section{Introduction}

The first step to establishing effective corporate governance mechanisms is to establish a board of directors with the appropriate balance of skills, expertise, independence and knowledge of the company so that it can perform its duties effectively. The Board of Directors has a central role as a mechanism for corporate governance. That the company's policies are specific, it has a solid regulatory environment, and there is protection of shareholders' rights, in addition to high levels of transparency and disclosure, as well as safeguarding the interests of the company and all shareholders.

The structure of the board of directors as a corporate governance mechanism has been of great interest in recent years, by academics, and market participants and regulatory bodies. Where it is often assumed that the financial performance of companies is determined mainly through the characteristics of the board, as the agency's theory suggests That in order to protect the interests of shareholders, it is assumed that the Board of Directors must perform effective control function, which is influenced by several factors such as Composition of the Board of Directors, The size of the board, And role duality, The diversity of the Council, Asymmetry of information, And the culture of the Council [1].

Krishnan and Yang identify delays in auditing as an unintended consequence of AS2 because of the additional layers of compliance required. This problem, together with other issues related to the delay of the review, indicates that the SO40 404, together with its explanatory guidance, adds a layer of complexity, which has affected the intention of the SEC to improve the timing of the release of the information. Add new reporting requirements External auditors should increase the time it takes to complete the audit. The board of directors has been sharply criticized in recent times by the decline in shareholders' wealth and the failure of companies, where the board of directors was in the limelight due to the failure of major companies such as WorldCom and Enron, And therefore some of the stated reasons for these failures are the lack of effective control functions, and the Council gave up control of the managers of companies seeking to achieve their own interests, in addition to the Council considered the lack of accountability to managers, As a result, all governance reforms, in particular, emphasized the appropriate changes to the Board of Directors in terms of composition, structure and ownership Configuration. One of the most important of these reforms is the need for the board to include the balance between executive and non-executive directors in order to ensure that decision-making, Not to be controlled by a particular faction, in addition to the responsibilities of the Chairman of the Board and Executive Director should not be carried out by the same person, to ensure a balance between powers and authorities [2].

The board of directors plays an important role in maintaining effective corporate governance; The Company's management is responsible for proposing and implementing key policies, However, the shareholders may not agree with these policies that can lead to the Agency's problem between management and shareholders, Thus, the Board of Directors is one of the mechanisms that can ease the agency's conflicts within the company, Moreover, in a dynamic environment, the board of directors becomes of great importance for the smooth functioning of organizations, Various functions are expected to be performed, for example, management oversight to reduce agency costs, Appointment and separation of administration, And provide access to resources. The Board also seeks to protect the interests of shareholders

*Corresponding author: Mohamed abd elmenam elshawarby, Department of Accounting, High Institute of Computer Science and Information Systems, New Cairo Academy, Egypt, Tel: +20663334491; E-mail: Ishwrby@yahoo.com

Received September 27, 2018; Accepted December 15, 2018; Published December 27, 2018

Citation: Elshawarby MAE (2018) The Characteristics of the Board of Directors and their Impact on the Delay of the External Auditor's Report by Applying to Companies Listed on the Egyptian Stock Exchange. J Account Mark 7: 305. doi: 10.4172/2168-9601.1000305

Copyright: @ 2018 Elshawarby MAE. This is an open-access article distributed under the terms of the Creative Commons Attribution License, which permits unrestricted use, distribution, and reproduction in any medium, provided the original author and source are credited. 
in a competitive environment while maintaining managerial accountability to achieve good corporate performance and effective application of corporate governance, A good corporate governance framework can benefit the company in ease of financing, lower cost of capital, better stakeholder interest, better performance of companies in general [3].

\section{Audit delay}

The financial statements are usually conceived in a timely manner in literature as the time it takes for the company to submit its financial statements before its shareholders in the annual year Meeting after the date of closing of this company. IASB (2008) considers the timing of making financial information available to users in a timely manner to influence their decision. Timing, therefore, requires the provision of information Available to users as soon as possible [4]. Have shown that the time is shorter between the company at the end of the financial year of the date of the auditor's report, the greater the interest that can be obtained from the audited financial statements.

\section{Research problem}

The Board of Directors has been sharply criticized recently because of the decline in shareholders' wealth and the failure of companies. The board was in the limelight due to the failure of major companies such as WorldCom and Enron. Some of the stated reasons for these failures are the absence of effective control functions. This sought to achieve their own interests, as well as the Board's lack of accountability for managers. As a result, governance reforms, in particular, emphasized appropriate changes to the Governing Council in terms of composition, structure, and ownership. So it was necessary to search for boards of management with a set of characteristics that improve efficiency and effectiveness and support the independence of the external auditor and try to limit the delay of external auditor's reports so that:

The problem of research can be the following main question:

Is there an impact on the characteristics of the Board of Directors on the delay of the external auditor's report?

This main question is divided into a series of sub-questions:

- Is there an impact of Independence of the board directors on the delay of the external auditor's report?

- Is there an impact of the Board of Directors' experience on the delay of the external auditor's report?

- Is there an impact of the size of the board of directors on the delay of the external auditor's report?

- Is there an impact of CEO-chairman duality on the delay of the external auditor's report?

- Is there an impact of the balance between the executive and non-executive directors of the Board on the delay of the external auditor's report?

\section{Research objectives}

The main objective for this study is examining the relation between characteristics of board directors and delay of external auditor's report and the sub objectives for this study are to:

- Examine the relationship between board size and audit report delay.
- Determine the relationship between board independence and audit report delay.

- Investigate the relationship between board experience and audit report delay.

- Examine the relationship between board role duality and audit report delay

- Determine the relationship between executive and nonexecutive members and audit report delay.

The importance of the study is that although there is a long and rich history of research into the reasons for the delay of the audit report, the bulk of the previous studies focus on customer characteristics such as size, profitability, internal control, industry type, Audit) or the external auditor's characteristics (eg. audit size, experience, specialization, and unaudited services). There is a search for an effect of corporate governance in the company on the delay of the audit report. However, the current study differs from these studies in that it dealt with the characteristics of the Board of Directors as one of the mechanisms of corporate governance to identify its effects in reducing the phenomenon of the delayed report of the External Auditor. Management in the process of monitoring and monitoring the external auditor and supporting his independence as well as follow up the steps of preparing financial reports with their financial and accounting expertise to increase the effectiveness of the Board of Directors to achieve the tasks and responsibilities entrusted to him, The appearance of the Board's characteristics is likely to directly affect the work and activities of the external auditor, including the time it takes to issue the audit report. However, despite this significance, [5] (based on a comprehensive review of literature) that the empirical analysis of any associate is almost non-existent.

The primary objective of this study is to address the imbalance in the literature by examining the relationship between the delayed audit report and the characteristics of the board of directors found in past literature to significantly influence the effectiveness of the board of directors. The characteristics of the five Board of Directors examined in this study are the independence of the Board of Directors, the financial and accounting expertise of the members of the Board of Directors, the size of the Board of Directors, the duplication of the functions of the Chairman of the Board and the Executive Director and the balance between executive members and non-executive members of the Board of Directors. The results will help the current study both regulators and interested in reform and the development of financial reports also improve the effectiveness of boards of directors, which give greater benefits to all participants in the capital market.

The report of the External Auditor is considered to be one of the most important components of the audit process, as it represents the final outcome of that process, which is the summary of the work of the External Auditor, It is considered one of the main references to determine the responsibilities of the external auditor towards the management of companies and their boards. The report of the External Auditor is an important document for the following reasons:

- It is a reliable and required document for all stakeholders who are interested in identifying the financial performance of the company.

- It is the effective means to provide information on the actual and potential effects of all operations of the company and 
maintain its entity and its relationship with others in a manner that satisfies the needs of users of the report information as much as possible.

- The report of the External Auditor shall include important matters to be taken by the General Assembly of shareholders, the most important of which is the approval or amendment of the final financial reports of the establishment, the discharge or non-discharge of the members of the Board of Directors,

- The adoption of the External Auditor of the financial statements of the company is the basis for the assessment of the tax on the outcome of the company.

It is reported that the longer the period of time elapsed between the end of the company's financial year And the shorter the issuance of financial statements, the more useful the information, Conversely, the value of the data is lower as the period between the end of the financial year and the financial statements increases, because competitors obtain this financial information from other alternative sources. Previous studies in accounting literature focus on financial markets in developed countries, while emerging markets In developing countries, there is little interest in this issue [6], although the issue of delaying the issuance of the report of the external auditor is an important issue in these emerging markets because there is no alternative source for investors to obtain reliable financial information except financial reports of companies until They were able to make different decisions [7].

The accuracy and timing of accounting information directly affect the prices of corporate securities. If financial information is less reliable, capital markets behave less efficiently. This result in poor distribution of venture capital increases the rate of return demanded by investors.

This study is based on a sample of companies listed on the Egyptian Stock Exchange in 2013 until 2016. This study is an extension of the previous studies in this field. The delay of issuing the report of the external auditor is measured as a number of days between the end of the financial year of the company and the date of the audit report The analysis of the multiple regression analysis was used to determine the relationship between the delay in the issuance of the audit report and five characteristics of the Board of Directors of the Company, namely:

- Independence of the Board of Directors

- The size of the Board of Directors

- Experience of the Board of Directors

- The balance between executive and non-executive members of the Board of Directors

- Duality of tasks and responsibilities between the Chairman of the Board of Directors and Executive Director.

The paper is organized as follows. Section 2 discusses the regulatory framework concerning characteristics of board directors in Egypt, and its impact on the delay of the external auditor's report of companies listed on the Egyptian stock exchange. Section 3 outlines the theoretical and empirical literature on the determinants of audit delay and posits the five hypotheses to be tested. Section 4 presents the study's research design. Section 5 contains the results of the data and sensitivity analysis. Section 6 concludes with a summary and discussion of the results, and an outline of the study's major contributions and implications.

\section{Literature Review}

The timely release of financial information by companies is an important aspect of financial reporting plays a key role in the information market and investment decisions taken by users. The delay in the external auditor's report affects the quality of financial information by not providing timely information to key stakeholders. In principle, it is said that there is an inverse relationship between the value of the information and the time it takes to prepare the financial statements, Specifically, the longer the time taken by the auditor To complete the audit process, as indicated in the delayed audit report, the stronger signal to the market where there may be negative audit problems.

The researcher then finds that The first step to establishing effective corporate governance mechanisms is to establish a board of directors with the appropriate balance of skills, expertise, independence, and knowledge of the company so that it can perform its duties and responsibilities effectively. The Board of Directors has a central role as a mechanism for corporate governance as the Board is responsible for ensuring that The company's policies are specific, it has a strong regulatory environment, there is protection of shareholders' rights, in addition to high levels of transparency and disclosure, as well as safeguarding the interests of the company and all shareholders.

The timing of financial reporting by companies is the basic component of general-purpose reporting quality. Previous research has shown that in time financial reports add content information, thus affecting the value of the company [8]. The length of the annual audit has been identified as the single most important determinant of timely financial reporting by firms [9]. Therefore, timely disclosure of audited financial reports by the External Auditor plays an important role in the value of the Company and reduces asymmetry in financial information [10]. Due to recent accounting disasters, lawmakers and investors have become increasingly concerned over time, as well as their demand for adequate and timely financial reporting. The factors that delay the report of the External Auditor have captured the interest of recent researchers; this motivation provided the researcher with the opportunity to undertake the current study because the users of the financial information demanded timely and high quality, which necessitates an in-depth study to try to do so.

Most of the previous studies related to the delay of the External Auditor's report focused on the determinants of this phenomenon, particularly the study of the impact of the evaluation of the quality of internal control on the delay of the External Auditor's report. They also measure the delay of the External Auditor's report and compare the results with measurement in accounting periods before applying sox [11].

The study noted that the evolution of the roles of the Board of Directors is dynamic, In view of the functions and responsibilities of the Council, the focus is no longer only on performance review, but at present the Council has become the mastermind in making sound business decisions, Organizations are moving towards long-term strategic directions and therefore the board should adopt broader roles to push organizations to achieve good financial performance, The Board of Directors can improve the performance of organizations when it has two important functions: First, to monitor and control executive management activities in order to balance management and the Board of Directors, Indirectly, the board of directors prevents any irregularities and thus contributes to good governance and transparency. Second: Review the evaluation of the performance of the administration, as well as advise them in identifying opportunities and alternatives available, strategic plans, and Share External Source of Knowledge. 
The other research [12] finds audit delay associated with weaknesses in internal control. Companies that suffer from physical weaknesses require more time to complete the audit process [13]. Research indicates that the delay in auditing affects the timing of accounting information, as well as the circumstances that are negative (Market reaction) [14] Audit delay results from various causes. Researchers find vague and subjective words in early interpretive guidance provided by the PCAOB contributions to audit delay [15]. Examine audit delay both pre and post SOX and find that companies with high non-audit service fees associated withered audit report lags [9]. Regulators need to understand the determinants of audit delay so they may effectively promulgate rules designed to decrease delay [16]. Feldman [17] find audit delay affects the timeliness of accounting information and also signals conditions which have a negative market reaction. Audit delay attributable to SOX 404 complexity and its supporting guidelines has received considerable attention from the SEC and its support agencies since 2004.

Corporate governance is another influential factor introduced in the literature. Previous research has assumed that it plays an important role in shaping and strengthening financial reporting [18]. Argues that one of its most important functions is to ensure the quality of the financial reporting process [19], while other authors have proposed much internal and external governance Mechanisms including the Board of Directors, external audit structures and ownership [20]. Argue that companies are strong Governance mechanisms can reduce client-related risks and reduce the need for material testing, thereby improving audit timing [21].

Using a sample of companies listed on the Egyptian Stock Exchange, [22] is piloting the impact of corporate governance characteristics on audit delays. The results of the study showed that the average delay in auditing Egyptian companies listed for 2007 was 67 days, ranging from 19 to 115 days. For corporate governance variables, Afify [22] shows that the independence of the Board of Directors, the two chief executive officers and the presence of an audit committee has had a significant impact on the audit delay. For the company's characteristics, Afify reveals that the size, profitability, and classification of the company are important determinants of audit delays. Both [23] verify the determinants of delays in auditing between listed Jordanian companies and found that the profitability ratio, the type of audit firm and the size of the company were negatively associated with the delay of the review. In examining the determinants of the delayed audit in Nigerian emerging markets, [24] showed that the financial performance of the company, the type of audit firm and the number of subsidiaries had a significant impact on the audit delay.

If the AS5 succeeds in simplifying the audit process, I expect to find a delay in the audit decreased, with the stability of other factors, after the implementation of AS5. This new standard increases the likelihood of detecting problems that affect audit delays such as maintaining the integrity of internal controls before they cause the material misstatement of the financial statements. This goal should guide auditors away from unnecessary actions to achieve desired results, reduce the complexity of audit and delay review [12]. The low delay in audit should result in accurate and timely disclosure of accounts, AS5 and the SEC's attempt to restore confidence in the US capital markets. If it can be shown that the audit delay has decreased after the AS5, the AS5 targets will appear to have led to the AS5 effectiveness.

It is clear from the review of previous studies that there is a scarcity in dealing with the relationship between the characteristics of the Board of Directors and the delay of the report of the External Auditor, especially in developing countries such as the Arab Republic of Egypt. This study attempts to contribute to support the characteristics that should be available in the Board of Directors, In order to reduce the phenomenon of delaying the audit report and the negative repercussions that have resulted and suffer from stakeholders with internal and external companies.

\section{Hypotheses}

In order to understand the magnitude of the problem caused by the delaying the audit report, is also Are necessary to review the audit delay in three periods. The review of delaying the audit report in the first period was postponed before the infamous corporate fraud and accounting failures of the 21st century. The second period reviews the delay in the audit after the issuance of SOX, during Effective period of AS2. The reviews for the third period assess the audit delay during the AS5 period. Research conducted during these three distinct periods focused on the various delays in audit.

The main contribution of the Board of Directors is the formulation of the Company's strategy and the exercise of the appropriate control function in all operations of the company [25]. Independent directors can share their independent views Participate actively in the discussion of the Governing Council. They will represent the shareholders of the Company's Board of Directors. As independence the person, they must ensure their presence and performance without any influence from insiders or management. The company appoints independent directors to monitor executive performance and senior management. Therefore, they will pursue shareholder interest by maximizing shareholder value. Zinkin has He said that independent managers must address several areas that contribute to the effectiveness of formulating the company's strategy. They must ask questions related to the company's business projects in, product segmentation, and customer value within market segmentation [26]. Independent directors with relevant industrial background and extensive experience will be more willing to challenge senior executives (CEOs) and management team in the board discussion.

The board of directors is a collective body that must work in the interests of shareholders. The Board requires a mix of executive and non-executive directors to follow up the interests of shareholders. Nonexecutive Directors of the Board of Directors will be unable to perform their duties effectively unless they are independent of management and ensure that they are impartial Ruling on working.

Independent directors are the person entrusted by the shareholders to represent them and will help to reduce Agency problems. In addition, the Corporate Governance Act and regulatory bodies recommend the composition of Board members should be balanced and composed of independent directors. However, mere compliance with recommendations is not enough if Independent managers failed to function effectively.

The following Figure 1 shows the variables of the study, which are the characteristics of the Board of Directors as an independent variable. It consists of a set of independent hypotheses, which are the independence of the Council, the size of the Council, the Board's experience, the Council's duality and the balance between executive and non-executive directors as a dependent variable.

\section{Board size}

The size of the board plays an important role in the corporate governance of companies, the world in general [27], several empirical 


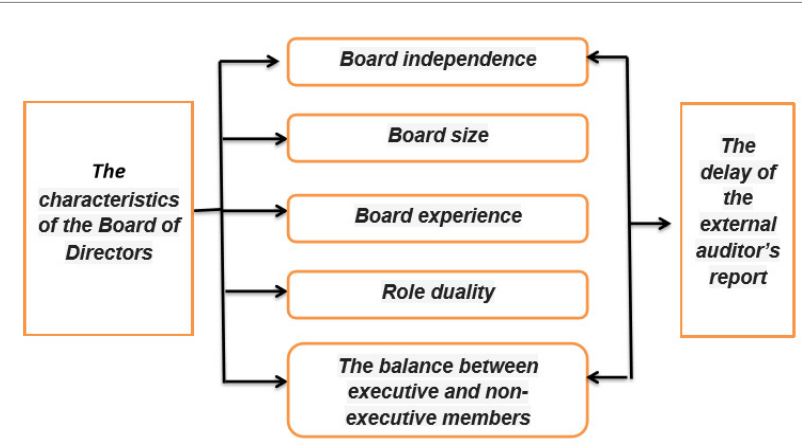

Figure 1: Conceptual model of the characteristics of the board of directors and their impact on the delay of the external auditor's report.

researches in accounting literature argued whether a small or large board improves management quality Responsibilities [28]. The larger plate according to [29] with Collective experience will be more capable of carrying out its duties and will disappear equally Management Control [30], in addition, Jensen [31] noted that the board with At least eight members may be effective and serve as effective board members. Based on The importance of the size of the former council and literature is supposed to: Relationship between Board size and delay of external auditor's report.

However, there is no consensus on whether larger or smaller boards improve the quality of financial reporting [32]. Although the relationship is Larger boards were said to be less effective in monitoring because of the difficulty of coordinating their activities and the capabilities of managers in "free ride" [33]. From an efficiency perspective, research shows that smaller councils may be more effective in terms of coordination, efficiency, communication, and decisionmaking, suggesting better management oversight High-quality financial reports [31]. Similarly, Bliss [34] argues that the larger boards are ineffective corporate governance mechanisms because it takes longer to make decisions and Poor communication and coordination and easily manipulated by senior management or dominant CEO. In the same context, Christensen [35] argue that smaller boards improve reports because the monitoring benefits associated with larger boards outweigh them Weak communication and slow decision-making. In a pilot study, $\mathrm{Li}$, [36] document a significant positive relationship between board size and review delay. Habib [37] says that as long as the board is able to do so monitoring management behaviour efficiently and effectively, audit delay is likely to be short, as control risks are assessed as less. Small councils are expected to be more effective in terms of coordination, efficiency, and communication, a positive relationship between the size of the board and the expected audit delay. Accordingly, this study assumes the following: H1 There is a significant relationship between the Board size and delay of external auditor's report.

\section{CEO duality role}

The Dominant personality or role duality means that the same person assumes the role of executive director and the role of the chairman of the board. This dual role thus reduces the ability of the board to control the conduct of the administration effectively and properly, which can lead to a minimum level of disclosure [38].

The role duality of the executive director creates a Structural Context that allows executives to serve their own interests and participate in opportunistic behaviours in managing the Corporate
Strategic Management for the following reasons:

a) The role duality of the executive director leads to the imbalance of power between the executive director and the chairman of the board, which is likely to limit the effectiveness of the council in monitoring the administrative activities and initiatives. The Structural Context of the dual role of the executive director gives him the legitimate authority without both the senior management team And the Board of Directors, increasing its impact on consensus building processes, Thus, the Executive Director, who has the official hierarchical authority in the functions of the Supervisory Board, provides a structural framework for administrative initiatives that may deviate from the interests of the shareholders.

b) The role duality of the Executive Director increases the asymmetry of information between the Executive Director and the Board of Directors, which are the source of the problems of the Agency, Executives are supposed to have an Unparalleled Superior Knowledge of the industry and the company's internal circumstances and, as a result, dual-role managers can take advantage of asymmetric information to influence the decision-making processes of the Board.

Thus, the combination of the positions of CEO and Chairman of the Board weakens the effectiveness of the Board in monitoring and effectiveness of the functions of the administration and thus increasing the costs of the Agency, and thus the effectiveness of the Board in controlling administrative opportunism in the management of the company's strategy is reduced.

Relationship between CEO duality role and delay of external auditor's report: The Duality of the Board of Directors is the structure of the company that integrates the positions of the Chairman and Chief Executive Officer. Argue that duplication of the Chief Executive Officer can improve administrative control, because it requires less contracting and reduced information asymmetry [39]. Although the problem is not necessarily a problem, the separation between these two roles is likely to provide basic checks and balances in managerial performance [19]. Argues that the role of the Council Chair is for monitoring the CEO; however, there is likely to be a lack of autonomy between management and the board if the CEO plays roles, and point out that dual executive directors can hamper the Board's ability to monitor management and thus increase agency costs [40]. The report of the Cadbury Commission (1992) does not encourage dual directors, because of perceived conflicts of interest when one person occupies two posts [34]. Argue that external auditors believe that the risk of audit failure is higher when the roles of the chairman and chief executive are combined, where there is greater scope to hide or refute relevant facts or commit fraud [33]. Thus, the duplication of the Governing Council proposes a more comprehensive audit, leading to longer delays. In practice [22] documented an important positive effect of dual function on the postponement of the review. As the separation between the two roles increases the strength of internal controls and reduces the risk, leading to more timely scrutiny, this study supposed to: $\mathrm{H} 2$ There is a significant relationship between CEO Duality Role and delay of external auditor's report.

\section{The balance between executive and non-executive members}

Despite the absence of legal discrimination between the powers, duties, responsibilities, and obligations of executives and non-executive directors, both play different roles on the Board. Balancing roles can be 
necessary to improve plate performance. Executives are employees of the corporation. They have accurate knowledge of the company and manage daily operations. Essentially, the CEOs manage the company and deal with the preparation and implementation of the company's strategic plans and business plans. Non-executive directors do not have executive responsibilities and generally focus on the Board. Since they do not participate in the day-to-day management of the company, they must be objective and have a more independent perspective. They should have the same access to information as executives and must unify management constructively when needed to ensure that the company achieves the agreed goals and objectives.

Relationship between The balance between executive and nonexecutive members and delay of external auditor's report: The ideal board will have a range of skills and experience relevant to the company. Research has indicated that companies with the highest performance are those governed by boards whose members are willing to challenge the status quo and who believe that health difference is a key element in a culture of continuous improvement. Thus, the role of non-executive directors on the board can balance the role of CEOs. In order to capitalize on the benefits of non-executive board members on the board, the Board of Directors must ensure that the roles remain distinct. This will enable non-executive directors to assist the Board in their objective and neutral views while the Executive Directors deal with the management of the Company. Board skills must be reviewed and analysed regularly to ensure optimal performance [41], this study Supposed to: H3 There is a significant relationship between the balance between executive and non-executive members and delay of external auditor's report.

\section{Board independence}

Independent directors are required to form board members and committees. For example, the members of the Audit Committee should be non-executive directors by a majority they are independent. This is to ensure that independent managers protect the interest of shareholders Controlled by management. The Egyptian Law on Corporate Governance has made an effort to strengthen the board's independence in the company through several recommendations. The Code emphasizes the composition of the Nominating Committee, which should consist of the majority of independent directors. Moreover, if the chairman of The Company is not independent, the majority of board members must be independent and the board must review the independence of independent directors annually.

Considered the issue of independence as an important factor in ensuring the Board's effectiveness through the monitoring and strategic roles of managers, the final factor of the independence plate by getting enough independent managers on board. They said that the manager's ability, desire, and internal environment may lead to the independent attitude of each manager. Roy [42] identified the effectiveness of nonexecutive directors in China through their formal independence, access to information, incentives provided and efficiency. However, they found that China's non-executive manager system was weak because of a lot of interference to control shareholders, and there was a lack of understanding of the functions of non-executive managers. [43] Studied the roles of independent directors in publicly listed companies in Australia by interviewing 30 managers. Co-managers agreed that the majority of non-executive directors (NEDs) on board will provide a guarantee of power balance or management relationship. Besides that, there was a difference between boards with non-executive directors and independent members. Independent managers will provide a variety of independent thinking, most of which can reduce the Risks of "collective thinking"
Relationship between board independence and delay of external auditor's report: The independence of the Council was considered one of the main determinants of its ability to protect the interests of the investor. There is considerable literature suggesting that councils should consist of the majority of non-executive directors, to alleviate the ethical problems that arise from the separation of ownership and control. And strengthen the audit process [33]. Document that independent managers take their role in monitoring more seriously more supportive of external auditors [44].

They are willing to pay the highest quality audit costs to protect their reputable capital, avoid legal liability and promote their interests Shareholders. Similarly, [45] argue that the independence and integrity of a manager play a key role in guarantee the reliability and quality of published financial statements. The study highlights the special contribution of non-executive managers in reducing profit management and thus improving the quality of reports. These results support the idea that the Board's effectiveness is positive Function of the proportion of external members. Carcello [46] assume that a more independent council takes greater responsibility for monitoring, thereby reducing the auditor's assessment of control risks, as this allows the auditor to determine the scope of their work, improves the timing of audits.

It has been argued that the board of directors has a significant impact on auditor's audit decisions, including their opinion [19]. For example, found that both the philosophy of administrative control corporate governance structures have also significantly influenced audit risk assessments and core testing. They suggest that auditors take corporate governance as a whole Structure in mind in the review. With regard to the quality of financial reporting, this means that the auditors believe that companies with a strong board of directors are less likely to exceed their limits when presenting their financial position. The strong board of directors may affect the estimated level of inherent risk and control. This, in turn, affects the nature, timing, and extent of the audit and leads to the preparation of progress reports. Accordingly, this study assumes that: H4 There is a significant relationship between the Board independent and delay of external auditor's report.

\section{Board experience}

The independent external members of board director who have a specific knowledge of the company's organization combine these desired characteristics and are therefore in a better position to practice both the monitoring and guidance function. Specifically, we propose and test the industry experience of external managers empirically as a measure that captures the superior capabilities of the Board of Directors to provide both oversight and advice. More importantly, we imagine that board experience is one of the most important determinants of the board's ability to perform its role in a way that enhances shareholder value.

The Sarbanes-Oxley Act of 2002 requires that the committees of institutions be fully composed of independent external directors. Listing rules on NYSE and Nasdaq (most) require listed companies to obtain a majority of independent external directors on their boards. In addition, major institutional investors, such as the Cal PERS Retirement System, recommend being the only CEO from within. This organizational trend, as well as pressure from institutional investors to reduce internal managers on the blackboard, can be said to limit the availability of knowledge of the company to the board of directors as the main decision-making body of the company. Coincidentally, the main focus of shareholders, the press, and many corporate 
Citation: Elshawarby MAE (2018) The Characteristics of the Board of Directors and their Impact on the Delay of the External Auditor's Report by Applying to Companies Listed on the Egyptian Stock Exchange. J Account Mark 7: 305. doi: 10.4172/2168-9601.1000305

governance experts has recently shifted from the board's independence to boardroom experience. In particular, in the aftermath Of the recent The financial crisis and fears that the industry experience in corporate boards is insufficient to raise them recent surveys among managers indicate that industry experience is the highest desired feature of new directors and one of the most successful skills in the area of board protection in the near future. (Wolfgang Drobtez,2014) estimate the expertise in the painting industry, known as the percentage External Directors with previous work experience in the same industry standard two-digit classification (SIC) Industry symbol, for all industrial companies in the S \& P 1500 index from 2000 to 2010 . The results show that companies with more experience in panel manufacturing with higher value compared to less experienced companies Managers on board.

Relationship between board experience and delay of external auditor's report: The Board experience was considered one of the main determinants of its ability to protect the interests of the investor. There is a relation between board directors and y of external auditor's delay because board directors experience enable the members of board to apply their responsibilities and duties by effectiveness and efficiency, through support the external auditor independence and control the relation between external auditor and executive manager.

There is a relationship between the board members' experience and the delay of the external auditor's report. This cumulative experience of the members of the Board of Directors helps the Council carry out the tasks entrusted to it and other responsibilities, Because it enables him to follow up the work of the External Auditor at all stages of the audit process and to overcome all obstacles encountered during the audit process, As well as strengthening the Board of Directors for the independence of the External Auditor to perform the audit of the highest quality, The financial and accounting expertise enables the members of the Board of Directors to follow up the financial management at all stages of preparing the financial statements in accordance with generally accepted accounting standards and principles. H5 There is a significant relationship between the board members' experience and delay of external auditor's report.

\section{Design}

\section{Sample and data collection}

The data are annual time series from 2013 to 2016 of 34 companies in 14 sectors in the Egyptian stock market. According to the Annual Report, the final sample contained 16 companies with complete and usable data, which are classified into five industry types: Construction and building materials (19 per cent), Chemicals (25 per cent), Communications (31 per cent), Food and drinks (13 per cent), Clothing and textiles (12 per cent). The data used in the study were obtained from two sources the first is annual reports of the Egyptian stock market -listed companies; and (2) the official website of the Egyptian stock market. Earlier work has documented that the delay of the external auditor's report is The Dependent Variable (Y). Can be influenced by several factors are The Independent Variables (X's) these include:

- The Board size

- The Board Independence

- The board members' experience

- CEO Duality Role
- The balance between executive and non-executive members

- Consequently, this study controls and isolates the potential effects of these variables on the delay of the external auditor's report.

\section{Regression model}

The dependent variable (Y) is delay of external auditor's report. Measured as the number of days that elapse from the close of the financial accounting period to the day the audit report is signed.

Independent variables are the following the characteristics of the Board of director's independence, board size, Board experience, role duality and the balance between executive and non-executive members. The strength of the association between delay of external auditor's report and the characteristics of the Board of Directors is measured using a linear regression model. Here, to achieve the purposes of the research, the linear regression model, which is represented by the following equation, will be used:

$\mathrm{y}=\mathrm{a}_{0}+\mathrm{a}_{1} \mathrm{x}_{1+} \mathrm{a}_{2} \mathrm{x}_{2+} \mathrm{a}_{3} \mathrm{x}_{3+} \mathrm{a}_{4} \mathrm{x}_{4}$

In order to test the strength of the linear regression model, a number of tests were used, the first being the independent personality test. The Pearson correlation matrix was calculated to determine the relationship between the independent variables in order to detect a linear correlation between the independent variables; the correlation coefficients between the variables are as follows: Depending on the results of Table 1, it is clear that most of the correlated relationships between variables $(0.01=\alpha)$, where the strongest correlation was found to be significant and statistically significant at the significance level was between the three variables (the board size, the Board of director's independence and the Board experience), and the weakest between the two variables (role duality and the balance between executive and nonexecutive members). Thus, it can be judged that there is no complete correlation between Independent variables.

This indicates that there is no statistically significant correlation between the independent variables in the correlation table, which enhances the possibility of using them in the model. The descriptive statistics for the dependent and independent study variables and Tables 2 and 3 show this.

\section{Test hypothesis}

The hypotheses are tested by identifying the effect of a set of variables (the board size, role duality, the balance between executive and non-executive members, the Board of director's independence and the Board experience) to delay the external auditor's report, Thus, the multiple regression model is used to study the effect of independent variables (the characteristics of the board of directors) on the dependent variable (delay of the external audit report), Table 4 shows the results of multiple regression analysis in an entered method.

\begin{tabular}{|c|c|c|c|c|c|c|}
\hline variables & $\mathbf{y}$ & $\mathbf{X 1}$ & $\mathbf{X 2}$ & $\mathbf{X 3}$ & $\mathbf{X 4}$ & $\mathbf{X 5}$ \\
\hline $\mathrm{y}$ & 1 & $-0.457\left(^{* *}\right)$ & 0.074 & -0.035 & $-0.402\left(^{(*}\right)$ & $-0.415\left(^{* *}\right)$ \\
\hline $\mathrm{X} 1$ & & 1 & -0.118 & 0.086 & $0.217\left(^{* *}\right)$ & $0.213\left(^{* *}\right)$ \\
\hline $\mathrm{X} 2$ & & & 1 & 0.025 & $-0.165\left(^{*}\right)$ & $-0.124\left(^{*}\right)$ \\
\hline $\mathrm{X} 3$ & & & & 1 & -0.051 & -0.043 \\
\hline $\mathrm{X} 4$ & & & & & 1 & -0.038 \\
\hline $\mathrm{X} 5$ & & & & & & 1 \\
\hline
\end{tabular}

** Correlation is significant at the 0.01 level (2-tailed).

* Correlation is significant at the 0.05 level (2-tailed). 
Citation: Elshawarby MAE (2018) The Characteristics of the Board of Directors and their Impact on the Delay of the External Auditor's Report by Applying to Companies Listed on the Egyptian Stock Exchange. J Account Mark 7: 305. doi: 10.4172/2168-9601.1000305

Page 8 of 10

\begin{tabular}{|c|c|c|}
\hline Variable & Acronym & Measurement \\
\hline \multicolumn{3}{|c|}{ Dependent variable } \\
\hline $\begin{array}{l}\text { delay of external } \\
\text { auditor's report }\end{array}$ & $y$ & $\begin{array}{l}\text { The number of days that elapse from the } \\
\text { closure of the financial accounting period } \\
\text { until the day the auditor's report is signed }\end{array}$ \\
\hline \multicolumn{3}{|c|}{ Independent variables } \\
\hline board size & $\mathrm{X} 1$ & The total number of directors on the board. \\
\hline role duality & $\mathrm{X} 2$ & $\begin{array}{c}\text { Dummy variable that equals } 1 \text { if the CEO } \\
\text { is also the chairman of the board, and } 0 \\
\text { otherwise }\end{array}$ \\
\hline $\begin{array}{l}\text { the balance between } \\
\text { executive and non- } \\
\text { executive members }\end{array}$ & $\mathrm{X} 3$ & $\begin{array}{l}\text { The proportion of non-executive directors to } \\
\text { the number of executives. }\end{array}$ \\
\hline $\begin{array}{c}\text { the Board of director's } \\
\text { independence }\end{array}$ & $\mathrm{X} 4$ & $\begin{array}{l}\text { The proportion of non-executive directors to } \\
\text { the total number of directors on the board. }\end{array}$ \\
\hline Board experience & X5 & $\begin{array}{c}\text { The percentage of those holding a certificate } \\
\text { Accounting or financial or related certificates } \\
\text { to the total number of members of the } \\
\text { Committee }\end{array}$ \\
\hline
\end{tabular}

Table 2: Statistics for the dependent and independent study.

\begin{tabular}{|c|c|c|}
\hline Variable & Mean & SD \\
\hline $\mathrm{y}$ & 58.11 & 18.12 \\
\hline $\mathrm{X} 1$ & 3.18 & 0.32 \\
\hline $\mathrm{X} 2$ & 4.45 & 1.43 \\
\hline $\mathrm{X} 3$ & 0.88 & 0.06 \\
\hline $\mathrm{X} 4$ & 0.36 & 0.18 \\
\hline $\mathrm{X} 5$ & 0.42 & 0.19 \\
\hline
\end{tabular}

Table 3: Descriptive statistics.

\begin{tabular}{|c|c|c|c|c|c|}
\hline Model & $\mathbf{R}$ & $\mathbf{R}^{\mathbf{2}}$ & Adjusted $\mathbf{R}^{\mathbf{2}}$ & $\begin{array}{c}\text { Std. Error of the } \\
\text { Estimate }\end{array}$ & R Change \\
\hline 1 & $0.611(\mathrm{a})$ & 0.389 & 0.352 & 15.152 & 0.378 \\
\hline \multicolumn{5}{|c}{ Table 4: Model summary. }
\end{tabular}

- Predictors: (Constant), the board size, role duality, the balance between executive and non-executive members, the Board of director's independence and the Board experience.

- Dependent Variable: delay the external auditor's report.

Table 3 shows that the value of the correlation coefficient between the independent variable and the dependent variable with a value of (0.378) indicating ( $\mathrm{R} 0.611$ ). The value of the limiting factor specified in (2) indicates that if an independent variable of the model is added, its value will increase even if the independent variable in the model, $\mathrm{t}$ therefore, The independent variables were able to explain $(35.2 \%)$ of the changes in the dependent variable and the rest were attributed to other factors. The overall Morality Test of the Multiple Regression Model was used. Table 4 presents the results of the variance analysis ANOVA to test the significance of the regression model.

a. Predictors: (Constant), the board size, role duality, the balance between executive and non-executive members, the Board of director's independence and the Board experience.

\section{b. Dependent Variable: delay the external auditor's report.}

Table 5 shows the analysis of variance, which aims at identifying the explanatory power of the model and for each independent variable, as shown in Table 5 it is clear that there is a high level of significance for the test (F), As shown in Table 5, it is clear that there is a high significance for the test (F) of 23,104 with a degree of freedom (4) and with a significance level of $(0.000=\mathrm{Sig})$ less than the significance level $(0.05 \geq \alpha)$ Thus, the regression model is appropriate to measure the causal relationship between the independent variables and the dependent variable, Thus, it can be said that at least one independent variable affects the dependent variable, which can be significant, and this is known by means of a significant test of multiple regression equation.

Dependent variable: delay the external auditor's report. Thus, as shown in Table 6 , the parameter is the constant limit $(0.000=\operatorname{Sig})$ less than the significance level $(0.05 \geq \alpha)$, thus, the appearance of the slope parameter is significant The importance of the independent variable in the model and the introduction of the constant limit value in the regression equation and where it reached Its value is $(143,012)$.

Test the main hypothesis: "There is a significant relationship between the characteristics of Board directors and delay of external auditor's report". Five hypotheses emerged from this hypothesis. The following are their tests as follows:

- Test the first sub-hypothesis: H1 there is a significant relationship between the Board independent and delay of external auditor's report.

Table 6 shows that the value of $(t)$ reached $(5,350)$, which is greater than its tabular value at a significant level $(0.000)$, which is less than the significance level $(0.05 \geq \alpha)$, The value of $(B)$ is $(-18.244)$ The decrease in the value of the dependent variable due to the increase of the independent variable, (B) was (-0.365) and enhances the result obtained. Therefore, the researcher considers the validity of the first sub-hypothesis is correct and that the increase in the Board size leads to limit the delay of the report of the External Auditor.

- Test the second sub-hypothesis: H2 There is a significant relationship between CEO Duality Role and delay of external auditor's report.

Table 6 shows that the value of $(t)$ reached $(-0,448)$, which is greater than its tabular value at a significant level (0.648), which is bigger than the significance level $(0.05 \geq \alpha)$, The value of $(B)$ is $(-0.424)$ The decrease in the value of the dependent variable due to the increase of the independent variable, $(\beta)$ was $(-0.032)$ and enhances the result obtained. Therefore, the researcher considers the second sub-hypothesis is incorrect and the existence of role duality leads to an increase in the delay of the report of the External Auditor.

- Test the third sub-hypothesis: H3 There is a significant relationship between the balance between executive and nonexecutive members and delay of external auditor's report.

\begin{tabular}{|c|c|c|c|c|c|c|}
\hline Model & $\begin{array}{c}\text { Source of } \\
\text { Variance }\end{array}$ & $\begin{array}{c}\text { Sum of } \\
\text { square }\end{array}$ & df & Mean square & F & Sig \\
\hline 1 & Regression & 20397.26 & 4 & 5063.52 & 23.104 & $0.000(a)$ \\
\hline & Residual & 31812.412 & 138 & 229.586 & & \\
\hline & Total & 52209.672 & 141 & & & \\
\hline
\end{tabular}

Table 5: The results of the variance analysis.

\begin{tabular}{|c|c|c|c|c|c|}
\hline & $\begin{array}{c}\text { Unstandardized } \\
\text { Coefficients }\end{array}$ & \multicolumn{2}{|c|}{$\begin{array}{c}\text { Standardized } \\
\text { Coefficients }\end{array}$} & & \\
\hline Model c & B & Std. Error & Beta & $t$ & Sig. \\
\hline (Constant) & 143.012 & 19.612 & & 7.496 & 0 \\
\hline X1 & -18.244 & 3.52 & -0.365 & -5.35 & 0 \\
\hline X2 & -0.424 & 0.952 & -0.032 & -0.448 & 0.648 \\
\hline X3 & -7.751 & 16.639 & -0.036 & -0.533 & 0.567 \\
\hline X4 & -41.788 & 6.904 & -0.413 & -6.177 & 0 \\
\hline X5 & -21.318 & 7.772 & -0.356 & -5.674 & 0 \\
\hline
\end{tabular}

Table 6: Coefficient. 
Citation: Elshawarby MAE (2018) The Characteristics of the Board of Directors and their Impact on the Delay of the External Auditor's Report by Applying to Companies Listed on the Egyptian Stock Exchange. J Account Mark 7: 305. doi: 10.4172/2168-9601.1000305

Page 9 of 10

Table 6 shows that the value of $(\mathrm{t})$ reached $(-0,533)$, which is greater than its tabular value at a significant level (0.567), which is bigger than the significance level $(0.05 \geq \alpha)$, The value of $(B)$ is $(-7.751)$ The decrease in the value of the dependent variable due to the increase of the independent variable, $(\beta)$ was $(-0.036)$ and enhances the result obtained. Therefore, the researcher considers the third sub-hypothesis is incorrect and the existence of the balance between executive and non-executive members leads to an increase in the delay of the report of the External Auditor.

- Test fourth sub-hypothesis: H4 There is a significant relationship between the Board independent and delay of external auditor's report.

Table 6 shows that the value of $(t)$ reached $(-6,177)$, which is greater than its tabular value at a significant level $(0.000)$, which is less than the significance level $(0.05 \geq \alpha)$, The value of $(B)$ is $(-41.788)$ The decrease in the value of the dependent variable due to the increase of the independent variable, $(\beta)$ was $(-0.413)$ and enhances the result obtained. Therefore, the researcher considers the validity of the first sub-hypothesis and that the increase in the Board independent leads to limit the delay of the report of the External Auditor.

- Test fifth sub-hypothesis: H5 There is a significant relationship between the board members' experience and delay of external auditor's report.

Table 6 shows that the value of $(t)$ reached $(-5.674)$, which is greater than its tabular value at a significant level $(0.000)$, which is less than the significance level $(0.05 \geq \alpha)$, The value of $(B)$ is $(-21.318)$ The decrease in the value of the dependent variable due to the increase of the independent variable, $(\beta)$ was $(-0.356)$ and enhances the result obtained. Therefore, the researcher considers the validity of the fifth sub-hypothesis and that the increase in the board members' experience leads to limit the delay of the report of the External Auditor.

\section{Conclusion and Recommendation}

Within the framework of the research problem and its objectives, the following results were achieved:

1. The first step to establishing effective corporate governance mechanisms is to establish a board of directors with a set of characteristics and an appropriate balance of skills, expertise, independence and knowledge of the company so that it can perform its duties effectively. The Board is responsible for ensuring that the company's policies are specific, has a solid regulatory environment, and there is protection of shareholders' rights, In addition to the high levels of transparency and disclosure, as well as the preservation of the interests of the company and all shareholders.

2. The most important characteristics to be met in the Board of Directors is the size of the board of directors, the independence of the members of the Board of Directors and the availability of experience and knowledge of the members of the Board in a manner that enables them to perform the tasks and responsibilities entrusted to them efficiently and effectively.

3. The existence of a competent and effective board of directors with a set of distinctive characteristics such as experience, knowledge, independence and the optimal size of its members affects the delay of the report of the external offices by limiting the delay of issuance of the external auditor, limiting the problem of asymmetry of information and preserving the shareholders' rights.
4. The validity of the first sub-hypothesis is correct and that the increase in the Board size leads to limit the delay of the report of the External Auditor.

5. The second sub-hypothesis is incorrect and the existence of role duality leads to an increase in the delay of the report of the External Auditor.

6. The third sub-hypothesis is incorrect and the existence of the balance between executive and non-executive members leads to an increase in the delay of the report of the External Auditor.

7. The validity of the fourth sub-hypothesis is correct and that the increase in the Board independent leads to limit the delay of the report of the External Auditor.

8. The validity of the fifth sub-hypothesis and that the increase in the board members' experience leads to limit the delay of the report of the External Auditor.

\section{Recommendation}

1. The need for legislation at the local and global level that enhances the characteristics of the board of directors in companies and its impact on delaying the issuance of the independent audit report so that it becomes mandatory for companies which in turn enhances the credibility and reliability of the financial statements, In addition to Conduct more future studies on the same topic of research for its importance.

2. Activate the role of professional bodies interested in accounting and auditing by issuing recommendations to audit offices and audit companies to comply with the issuance of audit reports to companies without delay in order to preserve the rights of the stakeholders in the company and to eliminate the information asymmetry.

\section{Future research}

The subject of the research needs more future studies, for example:

- The impact of the professional specialization of the members of the Board of Directors on the delay of the report of the External Auditor.

- As non-executive directors to delay the report of the External Auditor.

- The impact of the joint audit on the delay of the report of the External Auditor.

\section{References}

1. Uadiale O (2010) "The Impact of Board Structure on Corporate Financia Performance in Nigeria". Int J Bus and Manag 5: 155-166.

2. Abidin Z, Kamal NM, Jusoff K (2009) "Board Structure and Corporate Performance in Malaysia". Int J Econ Fin 1: 150-164.

3. Fauzi F, Locke S (2012) "Board structure, Ownership Structure and Firm Performance: A study of New Zealand Listed-Firms". Asian Academy of Manag $\mathrm{J}$ Account Financ 8: 43-67.

4. Carslaw APN, Kaplan SE (1991) An Examination of Audit Delay: Further evidence from New Zealand. Account Bus Res 22: 21-32.

5. Bedard J, Gendron $Y(2010)$ 'Strengthening the financial reporting system: Can audit committees deliver? Int J Auditing.

6. Bushee BJ, Core JE, Guay W, Hamm SJW (2010) "The role of the business press as an information intermediary". J Account Res 48: 1-19.

7. Khasharmeh H, Aljifi K (2010) "The timeliness of annual reports in Bahrain and the United Arab Emirates: an empirical comparative study". Int J Bus Financ Res 4: 51-71. 
Citation: Elshawarby MAE (2018) The Characteristics of the Board of Directors and their Impact on the Delay of the External Auditor's Report by Applying to Companies Listed on the Egyptian Stock Exchange. J Account Mark 7: 305. doi: 10.4172/2168-9601.1000305

Page 10 of 10

8. Blankley Al, Hurtt DN, MacGregor JE (2014) 'The relationship between audit report lags and future restatements'. Auditing: A J Practice \& Theory 33: 27-57.

9. Knechel WR, Sharma DS (2012) 'Auditor-provided nonaudit services and audit effectiveness and efficiency: Evidence for pre-and post-SOX audit report lags. Auditing: A J Practice \& Theory 31: 85-114.

10. Lee HY, Mande V, Son M (2009) 'Do lengthy auditor tenure and the provision of non-audit services by the external auditor reduce audit report lags? Int J Auditing 13: 87-104.

11. Ettredge ML, Li C, Sun L (2006) The impact of SOX Section 404: Internal control quality assessment on audit delay in the SOX era. Auditing: A J Practice \& Theory $25: 1-23$

12. Bidard JC, Graham L (2011) Detection and severity classifications of Sarbanes Oxley Section 404 internal control deficiencies. Account Review 86: 825-855.

13. Bryant-Kutcher L, Peng EY, Zvinakis K (2007) The impact of the accelerated filing deadline on timeliness of $10-K$ filings. SSRN Electronic Journal.

14. Impink J, Lubberink M, Praag B, Veenman D (2012) Did accelerated filing requirements and SOX Section 404 affect the timeliness of $10-\mathrm{K}$ filings? Rev Account Stud 17: 227-253.

15. Orcutt JL (2009) The case against exempting smaller reporting companies from Sarbanes-Oxley Section 404: Why market-based solutions are likely to harm ordinary investors. Fordham J Corporate \& Finan Law 14: 325- 414.

16. Leventis S, Weetman P, Caramanis C (2005) Determinants of audit report lag: Some evidence from the Athens stock exchange. Int J Auditing 9: 45-58.

17. Feldman RB, Rosenfeld B, Lazar R, Segal B (2006) Computerized retrieval and classification: An application to reasons for late filings with the Securities and Exchange Commission. Intelligent Data Analysis 10: 183-195.

18. Fama EF, Jensen MC (1983) "Separation of ownership and control". J Law and Econo 26: 301-325.

19. Cohen J, Krishnamoorthy G, Wright A (2004) "The corporate governance mosaic and financial reporting quality". J Account Literature 23: 87-152.

20. Haniffa R, Hudaib M (2006) "Corporate governance structure and performance of Malaysian listed companies”. J Bus Finan Account 33: 1034-1062.

21. Nelson S, Shukeri S (2011) "Corporate governance and audit report timeliness: evidence from Malaysia”. Account in Asia 11: 109-127.

22. Afify HAE (2009) "Determinants of audit report lag: does implementing corporate governance have any impact? Empirical evidence from Egypt". J Applied Account Res 10: 56-86

23. Alkhatib K, Marji Q (2012) "Audit reports timeliness: empirical evidence from Jordan”. Procedia-Social and Behavioral Sciences 62: 1342-1349.

24. Elijah A (2015) "Corporate attributes and audit delay in emerging markets: empirical evidence from Nigeria". Int J Bus Social Res 5: 1-10.

25. Zinkin J (2010) Independent directors must learn to ask CEOs the right questions.' Auditing: A J of Practice \& Theory 31: 85-114

26. Fuzi SFS, Rahim M, Tan A (2012) Factors influencing Performance of Independent Directors in Malaysia, 2012 IEEE Symposium on Humanities. Sci Eng Res.

27. Salihi AA, Jibril RS (2015) The Effect of Board the Size and Audit Committee the
Size on Earnings Management in Nigerian Consumer Industries Companies. Int $\mathrm{J}$ Innovative Res and Development 4: 84-91.

28. Hassan YM (2016) Determinants of audit report lag: Evidence from Palestine. $\mathrm{J}$ Account in Emerging Econ 6: 13-32.

29. Akhtaruddin M, Hossain MA, Hossain M, Yao L (2009) Corporate governance and voluntary disclosure in corporate annual reports of Malaysian listed firms. J Applied Manag Account Res 7: 1-19.

30. Hussainey K, Wang M (2010) Voluntary disclosure and corporate governance: Further UK evidence. Working paper Stirling University.

31. Jensen MC (1993) The modern industrial revolution, exit, and the failure of internal control systems. J Finance 48: 831-880.

32. Williams RJ, Fail PA, Armstrong RW (2005) "Top management team tenure and corporate illegal activity: the moderating influence of board size". J Manageria Issues 17: 4.

33. Clatworthy MA, Peel MJ (2010) "Does corporate governance influences the timeliness of financial reporting? Evidence from UK private companies". HEC Account Manag Control Department Res Seminar.

34. Bliss MA (2011) "Does CEO duality constrain board independence? Some evidence from audit pricing". Account Finan 51: 361-380.

35. Christensen J, Kent P, Stewart J (2010) "Corporate governance and company performance in Australia". Australian Account Review 20: 372-386.

36. Li Y, Zhang D, Wang X (2014) "The influence of corporation governance structure on internal control audit report lag: evidence from China". Account $\&$ Taxation 6: 101-115.

37. Habib A (2015) "The new Chinese accounting standards and audit report lag". Int J Auditing 19: 1-14

38. Hassan M (2013) "Corporate Governance Characteristics and Voluntary Disclosure: The Case of UAE Listed Corporations". Int Conference on Bus Econ Account Pp: 1-44.

39. Haniffa RM, Cooke TE (2002) "Culture, corporate governance and disclosure in Malaysian corporations". ABACUS 38: 317-349.

40. Bradbury M, Mak YT, Tan SM (2006) "Board characteristics, audit committee characteristics and abnormal accruals". Pacific Account Review 18: 47-68.

41. Kakabadse NK, Yang H, Sanders R (2010) The effectiveness of non-executive directors in Chinese state-owned enterprises. Management Decision 48: 10631079 .

42. Nowak M, McCabe M (2008) The independent director on the board of company directors. Managerial Auditing J 23: 545-566.

43. Carcello JV, Hermanson DR, Neal TL, Riley RA (2002) "Board characteristics and audit fees". Contemporary Account Res 19: 365-384

44. Peasnell KV, Pope PF, Young S (2000) "Accrual management to meet earnings targets: U.K. evidence pre- and post-Cadbury". The British Account Review 32 415-445.

45. Berghe VD, Baelden T (2005) The complex relation between director independence and board effectiveness. Corporate Governance 5: 61-83.

46. Peel MJ, Clatworthy MA (2001) "The relationship between governance structure and audit fees pre-Cadbury: some empirical findings". Corporate Governance: An International Review 9: 286-297. 